\title{
EXCEL 2007 PIVOTTABLES AND PIVOTCHARTS
}

\author{
Jan LAVRINČÍK - Milan KLEMENT \\ MICROSOFT OFFICE EXCEL 2007: KONTINGENČNÍ TABULKY A GRAFY
}

(AITKEN, P. G. Microsoft Office 2007 Excel 2007 : Kontingenčni tabulky a grafy. 1. vyd. Brno : Computer Press, 2009. 264 s. ISBN 978-80-251-2306-5.)

Letos už jsou tomu dva roky, co Microsoft vydal přepracovaný balík kancelářských programů s největšími změnami od verze 97. Knih zabývajících se obecnými náležitostmi ovládání, přechod na Excel 2007 najdeme na našem trhu ,pěknou řádku“. Nakladatelství Computer Press se však rozhodlo nechat přeložit knihu z anglického originálu Excel 2007: Pivot Tables and charts, kterou napsal Aitken P. G. a trend zvrátit. Univerzální programy šetří čas, prostor na pevném disku i peníze, ale uživatel musí dokázat využít plný potenciál funkcí, které aplikace typu Excel 2007 nabízí. Kontingenční tabulka je prostředek $\mathrm{k}$ přehledné vizualizaci vzájemného vztahu dvou statistických znaků. Právě statistické zpracování dat je průřezovým

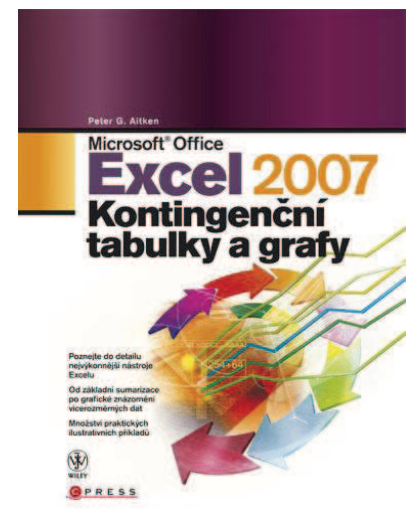
motivem knihy.

Kniha je členěna mimo kapitol i na oddíly, což je typický prvek knih z nakladatelství Computer Press. V obsahu najdeme informaci o základních částech $\mathrm{s}$ jejich názvy.

První oddíl nazvaný základy kontingentčních tabulek je dále členěn na tři kapitoly. Kapitoly mají obecný charakter, snaží se nám vtisknout do podvědomí pojem kontingenční tabulka a graf. Z názvu kapitol zdroje dat pro kontingenční tabulky a nástroje pro formátování kontingenčních tabulek je patrné, že nás autor pomalu začíná připravovat na složitější operace s kontingenčními tabulkami a grafy.

Druhá část knihy s názvem kontingenční tabulky a grafy: další možnosti, začíná kapitolou věnovanou práci s prvky kontingečních tabulek. Kapitola s číslem pět rozšiřuje znalosti získané v kapitole předcházející. Kapitola šest nazvaná kontingenční grafy navazuje na předchozí a ukazuje možnosti grafického zpracování statistických dat.
Třetí nejobsáhlejší a zároveň poslední oddíl si klade nelehký úkol, využití kontingenčních tabulek na maximum. Kapitola sedm pracuje s pojmem vícerozměrná data typu relační data, vytváření offline souboru $\mathrm{z}$ databáze serveru OLAP. Kapitola osm nám předkládá postupy práce s funkcemi typu získat data. Kapitola devět s pojmenováním alternativy kontingenčních tabulek se věnuje krátce i databázovým funkcím. Nosnou kapitolou třetí části je kapitola deset o programování kontingenčních tabulek v jazyce VBA (Visual Basic for Application). Touto z hlediska náročnosti nejobtížnejjší kapitolou kniha končí. Jako doplněk však autor ještě 20 stran věnoval přilohám. Příloha A - řešení problémů s kontingenčními tabulkami a grafy, př́loha $\mathrm{B}$ - rozdíly $\mathrm{v}$ kontingenčních tabulkách mezi verzemi Excelu a príloha $\mathrm{C}$ - úvodní kurz grafů v Excelu.

Kniha je velice vhodně doplněna možnostmi o propojení s VBA. Stejně jako kniha Johna Walkenbacha s názvem Excel 2007: Power programming with VBA jsou prriloženy i zdrojové soubory. Zdrojové kódy jsou velmi cenným objektem, vizuální pomůckou $\mathrm{k}$ pochopení fungování makra.

Kniha má obálku vyvedenou v moderní kombinaci barev a tvarů symbolizajících grafické zpracování statistických dat. Publikace díky poměrně nízkému počtu stran (264 stran) a měkkému přebalu má př́ijemnou hmotnost $\mathrm{z}$ hlediska mobility.

Knihu bychom mohli doporučit zájemcům o rozšíření znalostí použivání Excel 2007 o statistické funkce a grafy. Výborným doplňkem může být i pro studenty vysokých škol specializujících se na statistické zpracování dat na počítači bez použití specializovaných aplikací typu Statistika nebo SPSS+.
Mgr. Jan Lavrinčík, DiS.
KTEIV, Pedagogická fakulta UP
Žižkovo nám. č. 5, 771 40, Olomouc, ČR
Tel.: +420 585635813
E-mail: nobilis.felis@seznam.cz 